\title{
PROBLEMATIKA HUKUM YANG TIMBUL BERKAITAN DENGAN WEWENANG DISKRESI OLEH PENYIDIK UNTUK MEMILIH DAN MENENTUKAN"KETERANGAN AHLI" PORNOGRAFI
}

\author{
Oleh :
}

\section{ISMU GUNADI}

\begin{abstract}
authority of Diskresi by investigator in chosening and determining expert eyewitness or expert do not be supported clear legal fundament, in practice the straightening of law, role of investigator subyektip in environmental context [of] family, embraced religion and also view having the character of person of especial factor; which is on its its have an effect on to justice decision which frequently exactly disagree with expectation justice of society that is light crime decision that is attempt crime.
\end{abstract}

keyword: Diskresi, pornography/pornoaksi, expert boldness.

\section{PENDAHULUAN}

Pornografi serta Pornoaksi dalam konteks kelndonesian sangat erat kaitannya serta tidak dapat dipisahkan dengan nilai moral dan agama. Disisi lain jika dilihat dalam perspektif Negara sekuler maka persoalan pornografi dan pornoaksi tidak ada keterkaitan dengan persoalan moralitas yang bersendikan agama; hal ini sejalan dengan paham positivisme (aliran hukum murni) yang intinya memisahkan secara tegas antara hukum dengan moral.

Sementara itu dalam perspektf hukum yang berlaku di Negara kesatuan Indonesia yang bersendikan dan berdasarkan kepada Ketuhanan yang Maha Esa nampak jelas bahwa peran Negara dalam mengatur tata kehidupan masyarakatnya tidaklah dapat dipisahkan dari nilai nilai moralitas yang bersendikan agama. Tetapi ada yang perlu digaris bawahi adalah konsepsi bahwa Indonesia bukan pula Negara Agama.

Dengan demikian maka yang menjadi persoalan adalah nilai nilai ideal yang dibingkai hukum positif dalam tataran praktek penerapanya mem-butuhkan manajemen operasional hukum yang terikat oleh prosedur tetap ( Hukum Acara ) serta tidak dapat dipisahkan dari peran para pelaksana hukum itu sendiri; Selanjutnya nilai nilai ideal hukum 
diterjemahkan oleh pelaksana hukum secara nyata'dalam merespon kebutuhan masyarakat terhadap peran hukum dengan segala fungsinya tentunya haruslah berdasarkan pedoman dan tata cara yang telah diatur dan ditentukan.

Problematika praktek penegakan hukum berkaitan dengan persoalan pornografi dan pornoaksi menjadi debatible ketika pandangan masyarakat yang sedemikian heterogen (beragam agama dan nilai moralitas serta kepercayaan, persepsi yang melekat dalam Individu, kelompok, komunitas adat dst) tentang pornografi dan pornoaksi harus dibingkai dalam satu frame yaitu putusan hukum yang berlaku secara umum dalam skala Nasional dan bersifat mengikat.

Sementara itu, penyidik yang bertugas sebagai operator hukum dalam menjalankan tugasnya untuk mengoperasionalkan hukum tidak dibekali instrument khusus yang dapat dipedomani sebagai bahan acuan, apakah tindakan tertentu yang dilakukan oleh individu atau kelompok individu memenuhi unsur pasal yang disangkakan, dalam arti dapat disebut sebagai melakukan kejahatan atau tindakan pornografi.

Arahan atau pedoman yang ada adalah ketentuan materiel yang ada dalam undang undang tidak memberikan batasan pengertian apakah yang dimaksud pornografi atau pornoaksi, tidak ada tafsir yuridis yang dapat dijadikan landasan untuk menjaga nilai kepastian hukum, penyidik hanya dibekali ketentuan formil dalam hukum acara pidana yaitu kehadiran keterangan ahli yang dalam praktek seringkali disebut sebagai saksi ahli.

Barangkali dapat dipahami jika pembuat undang-undang tidak memberikan batasan tentang apakah yang dimaksud pornografi dan pornoaksi, mengingat sedemikian sulitnya untuk mendefinisikanya, maka oleh undang undang diserahkan penuh kepada perkembangan kebudayaan masyarakat dalam menilai hal hal yang bersifat porno atau tidak, yang untuk selanjutnya persepsi masyarakat tersebut diwakili oleh mereka yang mempunyai pengetahuan dan keahlian dalam memberikan pendapatnya tentang nilai nilai yang perlu dijaga oleh hukum agar pornografi dan pornoaksi tidak berkembang dan 
menggerus moralitas bangsa.

Dengan demikian maka arahan yang diberikan oleh undang melalui hukum acara kepada penyidik adalah keterangan ahli, dengan harapan agar keahlian dan pengetahuannya dapat membantu penyidik untuk membuat terang apakah tindakan individu atau kelompok individu

Permasalahan berikutnya adalah siapakah yang dapat dikatagorikan mempunyai kapasitas pengetahuan dan keahlian sehingga pendapatnya layak dan dapat diterima secara yuridis dan sosiologis mewakili kepentingan hukum berkaitan dengan ukuran porno atau tidak?. Barangkali jika menyangkut permasalahan lainnya sebagai pembanding misalnya ahli perbankan maka dapat dengan mudah untuk menetapkanya, atau ahli kedokteran, ahli senjata, ahli konstruksi, karena secara akademik ada pendidikanya, tetapi pornografi tidak ada yang berani menyatakan dirinya ahli dibidang tersebut. Apalagi jika parameternya ternyata bersentuhan dan menembus batas batas nilai nilai agama dan moral.

Permasalahan ini oleh hukum diserahkan penuh kepada operator hukum dalam hal ini kepada penyidik untuk menggunakan kewenanganya dalam bentuk diskresi.

\section{Kewenangan Diskresi}

Prayudi Admosudirjo mengatakan: istilah diskresi,berasal dari kata discretion (Inggris), freis ermessen (Jerman) diartikan sebagai kebebasan dalam melakukan tindakan atau mengambil keputusan menurut pendapat sendiri. (Prajudi, Atmosudirdjo, 1981 :33)

Kewenangan yang diberikan oleh Undang-undang atau atas kuasa Undangundang untuk bertindak berdasarkan pada asas wewenang:

a. Menurut dasar dan atau alasan yang dapat disebut fundamen.

b. kebenaran yang menjadi pokok dasar atau tumpuan berfikir dan

c. Cita-cita yang menjadi dasar.

Menurut Djoko Prakoso Jika langkah dalam melaksanakan wewenang diskresi tidak sesüai dengan asas wewenang yang berlaku, maka dapat dikategorikan sebagai perbuatan penyalahgunaan wewenang. (Djoko, Prakoso, 1997 : 144)

Ada beberapa prinsip dasar yang melandasi wewenang diskresi penyidik yakni :

a. Tidak bertentangan dengan aturan 
hukum

b. Tindakan tersebut selaras dengan kewajiban hukum yang mengharuskan melakukan tugas jabatan;

c. Tindakan yang dilakukan penyidik tersebut dalam batas patut dan masuk akal dan termasuk dalam lingkungan jabatannya;

d. Melakukan langkah yang layak dalam hal keadaan yang mendesak dan memaksa serta;

e. Memperhatikan serta menjunjung tinggi hak asasi manusia (HAM).

Wewenang diskresi penyidik sesuai dengan asas-asas hukum yang ada termasuk asas legatitas yang berarti sah menurut hukum dan berdasarkan perundang-undangan yang berlaku. Sedang asas kewajiban (plicht matigheid) yang memberi keabsahan langkah Polri selaku penyelidik maupun penyidik yang bersumber kepada kekuasaan dan kewenangan umum diambil demi memelihara ketertiban dan keamanan serta terciptanya rasa keadilan dalam masyarakat.

Arrest Hoge Raad tanggal 25 Januari 1892 dan tanggal 11 Maret 1914. menjelaskan bahwa untuk sahnya perbuatan kepolisian seperti wewenang diskresi penyidik (rechtmatig) tidak hanya harus berdasarkan peraturan perundangundangan (wettelijk voorschrif) saja tetapi masih ada persyaratan lain yang harus dipenuhi antara lain sebagai berikut;

1. Apa yang dilakukan Polri sebagai wewenangnya tidak boleh bertentangan dengan peraturan perundang-undangan,

2. Bahwa langkah tersebut untuk melindungi hak-hak orang lain,

3. Langkah itu untuk mempertahankan ketertiban, ketentraman dan keamanan umum.

Jika dicermati Arrest Hoge Raad tanggal 19 Maret 1917 yang menyatakan bahwa suatu tindakan dapat dianggap rechtmatig dan sesuai hukum yang berlaku sekalipun tanpa pemberian kuasa secara khusus oleh undang-undang, asalkan berdasarkan asas kewajiban untuk bertindak berdasarkan undangundang ( Soebroto Brotodiredjo, / 1983 majalah Bhayangkara, Jakarta).

Menurut pendapat penulis wewenang diskresi dikatakan sah menurut hukum apabila kewenangan umum dalam melaksanakan tugas tersebut karena didasarkan atas kewajiban. Polri dalam mengambil langkah perlu ukuran 
PERSPEKTIF Volume XI No.3 Tahun 2006 Edisi Juli

kewajibannya (machtplicht massigen crmessen) dalam batas-batas yang berdasarkan peraturan perundangundangan.

Ada empat asas yang membatasi langkah kepolisian berkaitan dengan penentuan kewajiban, yakni;

1. Asas keperluan (notwendig, noodzakclijk) yakni, bahwa. tindakan dilakukan dengan pertimbangan mencegah terjadinya suatu anggapan yang merupakan suatu ancaman dan membahayakan kehidupan masyarakat

2. Asas masalah sebagai patokan yakni, tindakan yang dilakukan oleh Polri harus obyektif dan tidak diperbolehkan untuk kepentingan pribadi (individu) dan atau kelompok tertentu.

3. Asas tujuan sebagai ukuran yakni, tindakan yang dilakukan harus sesuai dengan tujuan yaitu mencegah timbulnya suatu gangguan keamanan dan ketertiban.

Asas keseimbangan (evenredig) yakni, tindakan tersebut dilakukan guna menjaga suatu keseimbangan antara sifat lemahnya suatu tindakan dengan besar kecilnya suatu gangguan yang terjadi. (Djoko, Prakoso, 1997 : 151)
Keempat azas kewajiban tersebutlah yang dipergunakan Polri dalam melakukan wewenang diskresi khususnya terhadap tindakan represif maupun preventif. Wewenang diskresi tersebut dapat dilihat diantaranya dalam pasal 5 ayat (1) butir 4 dan pasal 7 ayat (I) KUHAP maupun dalam pasal 18 ayat (I) UU nomor 2 tahun 2002 tentang Pokok-Pokok Kepolisian Negara Republik Indonesia.

Ketentuan ini mewajibkan Polri khususnya yang bertindak sebagai penyidik untuk melakukan beberapa. jenis langkah yang diperlukan misalnya memilih dan menentukan ahli/saksi ahli pornografi. Selain peraturan perundang-undangan tersebut ada juga jurisprudensi sebagai salah satu landasan hukum bagi wewenang diskresi penyidik yang mendasarkan kepada asas kewajiban yaitu Arrest Hoge Road (Putusan Mahkamah Agung) Belanda tanggal 19 Maret 1917 yang menyebutkan bahwa suatu tindakan (wewenang diskresi) dianggap sah asalkan berdasarkan kewajiban menurut undang-undang.

Pengertian tersebut juga tercermin didalam pasal 18 ayat (1) UU nomor 2 tahun 2002 tentang Kepolisian Negara Republik Indonesia yang menyebutkan Polri dalam melakukan tugas dan 
wewenangnya dapat mengambil langkah atas inisiatif sendiri.

Pengertian inilah yang dijadikan dasar wewenang diskresi oleh penyidik dalam memilih dan menentukan ahli pornografi. Wewenang diskresi ini meliputi penentuan siapa orangnya yang memenuhi kriteria ahli pornografi maupun berapa jumlahnya. Dalam KUHAP dapat ditemukan beberapa pasal yang mengatur tentang wewenang diskresi penyidik dalam memilih dan menentukan ahli seperti Pasal 7 (1) g KUHAP dan Pasal 7 (1) h KUHAP, melalui pasal ini penyidik bebas untuk memilih dan menentukan siapa yang ditunjuk untuk bertindak sebagai ahli pornografi dan berapa jumlah orang ahli yang dibutuhkan oleh penyidik sangatlah tergantung dan wewenangnya, disamping itu perlu pula diperhatikan ketentuan pasal Pasal 120 (1) KUHAP, Pasal 179 (1) KUHAP,

Apabila diperhatikan pasal 7 ayat (1) huruf g, huruf h, pasal 120 ayat (1) dan pasal 179 ayat (1) KUHAP jelas nampak bahwa keseluruhan ketentuan tersebut mengatur wewenang diskresi penyidik guna melakukan penyidikan, seperti memanggil dan mendatangkan seorang ahli pornografi untuk diminta pendapatnya.
Dalam kaitan ini, KUHAP belum mengatur tentang siapa dan berapa orang ahli yang diperlukan termasuk tentang kriteria orang yang bertindak sebagai ahli pornografi tersebut. Kemudian, jika ditelaah lebih lanjut dan pasal 5 ayat (I) huruf a angka 4 Jo pasal 7 ayat (1) huruf j KUHAP yang menyebutkan bahwa penyelidik dan penyidik berwenang mengadakan langkah lain menurut hukum yang bertanggung jawab.

Dengan berpedoman kepada pasal 5 ayat (1) huruf a angka 4 KUHAP dan pasal 7 ayat (1) huruf j KUHAP, yang isinya seperti diuraikan diatas, dapat dilihat bahwa wewenang diskresi penyidik untuk memilih dan menentukan ahli pornograli secara umum telah diberikan pedoman.

Pedoman tersebut adalah syarat agar langkahnya tidak bertentangan dengan aturan hukum, selaras dengan kewajiban hukum, patut dan masuk akal, dengan pertimbangan yang layak serta menjunjung tinggi HAM Hal tersebut perlu diperhatikan tentunya sebelum penyidik melakukan upaya paksa khususnya penangkapan, penahanan, penggeledahan, penyitaan serta langkah penyidikan lainnya.

Untuk kepentingan tersangka penyidik berkewajiban memperhatikan 
syarat diatas agar dapat menemukan ahli pornografi yang tepat. Sebagaimana pembahasan tersebut diatas bahwa yang bertindak sebagai ahli pornografi ternyata memiliki disiplin keilmuan yang berbedabeda namun masih belum ada diantara mereka yang ahli dan yang pandangannya tentang pornografi didasarkan atas ayat-ayat kitab agama. Oleh sebab itu, batasan wewenang diskresi penyidik dalam menentukan ahli pornografi seyogyanva diprioritaskan kepada ahli pornografi yang pendapatnya mendasarkan kepada kitab agama.

Karena visi atau pandangannya mendasarkan kepada ayat-ayat dalam hukum agama diharapkan nilai pembuktiannya akan lebih akurat. Apabila dianggap perlu, penyidik dapat meminta pendapat ahli lainnya atau orang yang memiliki keahlian khusus yang masih ada hubungannya dengan kewanitaan seperti ahli dan pusat penelitian studi wanita Perguruan Tinggi (Vide Pasal 120 ayat (KUHAP)

\section{PETAPORNOGRAFI}

Jika pengertian pornografi dalam arti sempit adalah hanya menyangkut soal soal yang berkaitan dengan ditempat umum mempertunjukkan, menyiarkan atau menempelkan suatu tulisan, cerita-cerita yang berisi dan bernuansakan sexual serta gambar-gambar, benda porno yang melanggar kesusilaan dan yang dapat menimbulkan nafsu birahi bagi yang membaca atau melihatnya khususnya bagi kalangan kaum muda usia, diatur didalam pasal 282, 283 dan 533 ke 1, 2, 3 KUHP.

Sementara itu pengertian pornografi dalam arti luas adalah apa yang termuat dalam Buku II bab XIV KUHP dengan judul Kejahatan tentang kesusilaan yang meliputi pasal 281 sampai dengan pasal 303. Mendasarkan kepada pandangan Pompe tentang "strafreeht onzede1ijkheid" Omar Senoadji menjelaskan pengertian tentang tindak pidana kesusilaan yang tidak hanya terbatas pada persoalan pornografi, melainkan juga meliputi hal-hal yang berkaitan dengan pelecehan sexual dan perjudian.

Hukum pidana positif yang berkaitan dengan pornografi yang masih berlaku sampai saat ini adalah Bab XIV Buku 11 KUHP dengan judul kejahatan terhadap kesusilaan, termasuk didalamnya Pasal 300, 301, 302 dan 303 yang isinya adalah larangan terhadap perjudian. Jika 
ditelaah ternyata pasal-pasal tersebut sama sekali tidak ada hubungannya dengan kesusilaan khusus-nya sexual.

Pasal-pasal tersebut diatas merupakan tindak pidana terhadap kekayaan seseorang. Dengan demikian tindak pidana susila dalam arti luas tidak hanya mengenai masalah pornografi saja tetapi juga mencakup hal-hal yang berkaitan dengan zinah dan pelecehan sexual lainnya.

Dalam penyidikan kasus tindak pidana pornografi kewenangan sepenuhnya ada pada penyidik untuk menentukan siapa yang bertindak sebagai ahli pornografi. Keterangan yang diperlukan harus didukung oleh pendapat yang mendasarkan kepada hukum agama, artinya visi atau pandangannya mendasarkan kepada ayat ayat dalam kitab agama. Bila masih diperlukan dapat ditambah dan pakar lain sesuai keahliannya seperti psikolog maupun dan unsur pendidik, dengan bukti keterangan ahl/saksi ahli ini akan mempermudah pengungkapan suatu perkara.

Dengan demikian tindak pidana susila dalam arti luas tidak hanya mengenai masalah pornografi saja tetapi juga mencakup hal-hal yang berkaitan dengan zinah dan pelecehan sexual lainnya.

\section{KRITERIA ATAU KUALIFIKASI AHLI PORNOGRAFI}

Kewenangan diskresi penyidik untuk memilih dan menentukan ahli / saksi ahli pornografi pada setiap individu penyidik berbeda, maka berbeda pula cara pandang untuk memilih ahli/saksi ahli pornografi dimaksud. Demikian juga yang bertindak sebagai ahli/saksi ahli pornografi pandangannya berbeda-beda, karena latar belakang pekerjaan yang berbeda. Masing-masing ahli tersebut memiliki disiplin keilmuan yang berbeda pula.

Dengan demikian keterangan ahli/ saksi ahli pornografi yang diperoleh penyidik akan memiliki nilai pembuktian akurat yang pada giliranya akan berdampak terhadap putusan Pengadilan yang mana secara langsung atau tidak langsung bersentuhan dengan nilai kepastian dan keadilan yang diharapkan oleh para pencari keadilan.

\section{KRITERIA ATAU KUALIFIKASI AHLI PORNOGRAFI}

Menyimak hasil penyidikan kasus tindak pidana pornografi yang tersangka/ 
terdakwanya pimpinan redaksi majalah TOP dengan Berkas Perkara Nomor BP/137/IX/1999/Ditserse tanggal 7 Juli 1999, dimana saksi ahlinya terdiri dari seorang ahli pornografi yang bertindak mewakili instansi dan yang lain bertindak selaku pribadi, telah memberikan kesaksian yang diharapkan dapat membuat terang dalam pemeriksaan perkara tersebut.

Pengaturan wewenang diskresi penyidik yang begitu luas batasannya khususnya dalam memilih dan menentukan ahli pornografi. Untuk itu dalam penanganan, penyidikan kasus-kasus yang berhubungan dengan tindak pidana pornografi baik dalam arti luas maupun sempit sebaiknya yang berasal dan Departemen Agama RI/Kanwil Depag Propinsi dan memiliki kriteria sebagai berikut:

a. Ahli Agama Islam.

b. Ahli Agama Nasrani (Kristen dan Katholik).

c. Ahil Agama Hindhu dan lain-lain.

Disyaratkan agar masing-masing mereka yang bertindak sebagai ahli pornografi tersebut minimal berpendidikan S-1 dibidangnya, yang diharapkan keterangan yang diperoleh dan penelitian mereka yang berkaitan dengan masalah masalah pornografi yang diperlukan untuk bantuan teknis penyidikan, relatif akan lebih akurat dan memiliki nilai pembuktian yang validitasnya cukup tinggi. Dengan demikian mereka yang diminta menjadi ahli pornografi akan memiliki dasar hukum yang jelas, dan dalam rangka perlindungan hukum, bagi mereka akan semakin pasti juga dapat dipertanggung jawabkan menurut hukum.

\section{KRITERIA MENURUT HUKUM AGAMA}

Undang-undang Dasar Negara RI yang menegaskan bahwa negara Indonesia adalah berdasarkan kepada KeTuhanan Yang Maha Esa sehingga jelas tidak dapat dipisahkan antara hukum dengan moral dan agama, untuk itu dalam penanganan kasus pornografi dengan menggunakan keterangan ahli yang berdasarkan ayat-ayat dalam hukum agama bukanlah berarti menerapkan hukum agama tersebut ke dalam hukum positif tetapi pandangan hukum agama (Islam, Kristen Katholik dan Hindhu) diperlukan untuk menjelaskan dan mencari solusi tentang konsep pornografi, karena pornografi tidak dapat dilepaskan dan nilai moral dan agama. Pornografi dipandang dan sudut ayat-ayat dalam 
hukum agama yakni Islam, Kristen Katholik dan Hindhu dapat dijelaskan sebagai berikut:

\section{AGAMAISLAM.}

Sebagaimana yang diutarakan oleh Mohamad Djoko Poerwanto, bahwa pada prinsipnya agama Islam mengharamkan segala sesuatu yang menyebabkan, menimbulkan gairah sexual, baik secara langsung maupun tidak langsung.

Yang berhubungan langsung dengan manusianya antara lain seperti berbuat zinah, perkosaan, oral sex, bercumbu atau berpakaian yang tidak senonoh dan bukan pada tempatnya dan sebagainya. Hal tersebut diharamkan agama Islam. Sementara yang sccara tidak langsung misalnya melihat gambar porno, foto-foto model dengan pakaian tertentu, pakaian seronok atau berpakaian yang menonjolkan bagian tubuh tertentu yang mengundang perhatian dan menimbulkan gairah birahi sex dan lainlain.

Hal itu berlaku terhadap tulisantulisan, cerita-cerita yang bernuansakan cinta maupun sexsual, demikian pula terhadap patung atau tulisan-tulisan dan gambar yang memperlihatkan wanita telanjang dan memberikan corak porno yang berdampak negatif bagi yang melihatnya khususnya bagi kawula muda. Contohnya majalah Top No. 34 tahun II/31 Agustus 2000, No. 57 Tahun III/10 Agustus 2001 yang pada covernya terpampang sebuah foto seorang wanita dengan pakaian ketat yang hanya mengenakan $\mathrm{BH}$ dan celana dalam hal mana yang dapat menimbulkan gairah bagi yang melihatnya.

Demikian pula isi majalah tersebut memuat tulisan-tulisan tentang percintaan, hubungan gelap, per-selingkuhan, perempuan simpanan para pejabat maupun gambar porno wanita dalam segala bentuk.

Mengenal isi majalah tersebut lebih lanjut Mohamad Djoko Poerwanto mengatakan baik secara pribadi maupun mendasarkan kepada ayat-ayat dalam kitab Al-Quran gambar porno itu bertentangan dengan aturan agama Islam. Oleh karenanya majalah yang isinya demikian itu harus dilarang untuk diterbitkan karena akan menimbulkan gairah atau birahi sex bagi mereka yang melihat dan membacanya. Ada beberapa ayat-ayat Al-Qur'an yang berkaitan dengan pornografi antara lain berikut : Surat An-Nur ayat 31, Surat Al Ahzab ayat 
59, Surat Al-Isro' ayat 32 .

Surat Al-Isro' ayat 32, Surat A1Ahzab ayat 59 dan Surat An-Nur ayat 31 dapat dipetik maksudnya, bahwa dilarang bagi seorang wanita untuk menampakkan perhiasannya, kecuali yang nampak dan pandangannya dan hendaklah mereka menutupi kain kerudung kepadanya (SuratAn-Nur ayat 31).

Demikian pula yang menyangkut zina, telah dilarang dan diharamkan oleh agama Islam seperti yang terlihat dalam Surat Al-Isro' ayat 32, yang menyebutkan janganlah kamu mendekati zina, sesungguhnya zina itu perbuatan yang keji dan sejelek-jeleknya jalan.

Selanjutnya Surat Al-Ahzab ayat 59 telah menyebutkan pula adanya suatu perintah kepada Nabi Muhamad SAW dan terhadap istri-istri orang mukmin agar mengulurkan jilbabnya ke seluruh tubuh mereka. Demikian pandangan agama Islam tentang pornografi menurut Mohamad Djoko Poerwanto.

\section{KRITERIA MENURUT AYAT-AYAT DALAM KITAB INJIL}

Pornografi ditinjau dari ayat-ayat dalam kitab Injil ternyata berbeda-beda. Menurut Pendeta Condro Raharjo, pornograti dalam arti luas bisa juga menyangkut perbuatan asusila, seperti berzina, pemerkosaan, dan pelecehan sexual dalam bentuk lain. Bahkan dalam KUHP judi dan mabuk-mabukpun termasuk perbuatan asusila. Ayat ayat injil tersebut dalam Surat Amsal pasal 6 ayat 32, Surat Timotius Pasal 1 ayat 20, Surat Tesalonika Pasal 4 ayat 3, Surat Matius Pasal 5 ayat 27, Surat Markus Pasal 22 ayat 23, Surat Wahyu Pasal 3 ayat 18, Surat Imamat Pasal 18 ayat 6

Ayat ayat kitab injil tersebut jelas bahwa segala sesuatu yang ber-sangkutan dengan perzinaan dilarang bagi umat manusia. Untuk pornografi yang berhubungan dengan tulisan-tulisan/cerita cabul dan gambar-gambar porno / foto seronok seperti yang termuat dalam majalah Top dan Liberty, Pendeta Condro Raharjo berpendapat sebagai berikut : Dengan berpedoman kepada surat Markus Pasal 22 ayat 23 yang inti pokoknya baik itu zina (hubungan kelamin antara laki-laki dan perempuan yang bukan haknya) dan segala sesuatu yang dapat menimbulkan hawa nafsu birahi sexual, termasuk tulisantulisan dan gambar adalah porno.

Seperti yang dimuat dalam majalah Top dan Liberty tersebut bertentangan dengan ayat-ayat dalam kitab Injil agama Kristen Katholik. 
Demikian pula Surat Wahyu Pasal 3 ayat 18 yang menyuruh umat nasrani berpakaian putih (dalam arti bersih dan sempurna) supaya tidak kelihatan ketelanjanganrnu yang memalukan. Berdasarkan uraian diatas dapat disimpulkan bahwa pornografi baik berupa tulisan, cerita bernuansakan sexual dan gambar gambar porno sudah sejak zarnan dulu dilarang dalam ayat kitab Injil.

\section{Kriteria menurut ayat dan kitab Weda Sarasmuscaya}

Menurut I Gusti Ngurah Suteja bahwa pandangan agama Hindhu tentang pornografi menurut ayat dalam kitab Weda Sarasamuscaya adalah sebagai berikut:

Pada prinsipnya agama Hindhu mengajarkan pada umatnya untuk mengendalikan SADRIPU atau dengan apa yang disebut enam musuh yang Menjadi tantangan bagi manusia.Hal tersebut ada pada diri dan hati nurani manusia masing-masing, seperti:Kama artinya nafsu birahi, Krodha artinya Nafsu amarah, Lobha artinya nafsu angkara murka, Moha artinya kegelapan /kebingungan, Moda artinya kemabukan atau lupa ingatan, Matsarya artinya iri hati dan dengki

Keenam tantangan atau musuh tersebut, salah satunya adalah Kama, artinya nafsu birahi yang wajib dikendalikan. Menurut agama Hindhu kalau Kama sudah menguasai diri manusia maka berbagai kejahatan sexsual dapat terjadi seperti yang dilakukan binatang. Misalnya pemerkosaan, perselingkuhan, pelecehan sexual, penyimpangan sexual dan lain-lain.

Hal-hal yang berkaitan dengan pornografi yang tertuang dalam bentuk gambar porno, suara-suara maupun tulisan-tulisan yang bernuansakan cinta dan sexsual dapat merangsang timbulnya kama (nafsu birahi) pada setiap orang yang mendengar membaca dan melihatnya .

Sehubungan dengan masalah pornografi kitab "Sarasmuscaya" memberikan tuntunan dan pedoman yang diatur dalam Moka atau ayat-ayat yaitu Sloka 413, Sloka 422, Sloka 423

Sloka-sloka 413, 422 dan 423 tersebut, dapat disimpulkan betapa hebatnya nafsu birahi mempengaruhi manusia, terutama yang telah disebutkan pada sloka 413. Menurut I Gusti Ngurah Sutedja, sebagai pemuka agama Hindhu 
dengan mensitir isi dari sloka 413 yang salah satu intinya adalah untuk menangkis serangan nafsu birahi yaitu dengan jalan jangan melihat barang sesuatu yang merupakan keinginan nafsu birahi, termasuk rangsangan dengan hal-hal yang berbentuk membaca tulisan-tulisan yang bernuansakan cinta dan sexual dan melihat gambar gambar porno serta mendengarkan suara-suara yang menimbulkan birahi sexual tersebut.

Bersamaan dengan ini telah ditunjukkan salah satu mpedia cetak majalah Top yang bergambar beberapa pose seorang wanita dalam bentuk pakaian yang seronok seperti hanya memakai celana dalam dan $\mathrm{BH}$ saja, dengan kondisi tubuh yang montok dan menonjolkan bagian tubuh tertentu serta tulisan / cerita yang bernuansakan cinta dan sex. I Gusti Ngurah Sutedja sebagai pemuka agama Hindhu berpendapat bahwa hal-hal demikian sudah sangat menjurus kepada rangsangan birahi sexual bagi mereka yang melihat dan membacanya. Menurut I Gusti Ngurah Sutedja siapapun harus ditindak tegas bila kedapatan memperjual bahkan buku majalah dan tabloid yang berisi tulisan/ cerita sexual dan gambar porno karena akan merusak mental / moral bangsa.

KRITERIA MENURUT PARA PAKAR YANG ADA HUBUNGANNYA DENGAN PORNOGRAFI

Hasil penelitian terhadap salah satu BAP dalam kasus tindak pidana pornografi dengan berkas Nomor BP/137/ tanggal 7 Juli 1999 terdapat rumusan yang menyebutkan : Tersangka SG. STY sebagai Pimpinan Redaksi majalah TOP telah dengan sengaja menyiarkan, mempertunjukan atau menempelkan gambar-gambar porno, benda-benda yang melanggar kesusilaan pada tempattempat umum, mempertunjukkan suatu tulisan yang isinya dapat menimbulkan nafsu birahi bagi anak muda sebagaimana dimaksud dalam pasal 282, 283 dan atau 533 KUHP.

Dalam kasus tersebut yang bertindak sebagai ahli pornografi adalah orang-orang yang memiliki latar belakang disiplinn keilmuan yang berbeda, antara lain sebagai berikut : 
Tabel 1 : kualifikasi pendidikan dan latar belakang pekerjaan (jabatan) yang bertindak sebagai ahli

\begin{tabular}{|c|c|c|c|c|}
\hline No & Nama/Alamat & $\begin{array}{l}\text { Instasi/Swasta/ } \\
\text { Perorangan }\end{array}$ & $\begin{array}{l}\text { Latar Belakang/ } \\
\text { Disiplin Keilmuan }\end{array}$ & Ket \\
\hline 1 & $\begin{array}{l}\text { Munawar Tohir } 53 \\
\text { Th, Wonocolo } \\
\text { Belakang Pabrik } \\
\text { Kulit No. } 3 \text { Jemur } \\
\text { Wonosari } \\
\text { Surabaya }\end{array}$ & IAIN Sunan Ampel & S1 Filsafat Islam & Dosen \\
\hline 2 & $\begin{array}{l}\text { Astrid Rs. } \\
\text { Wiratna, } 40 \mathrm{~T}, \mathrm{JI} \\
\text { Wonorejo Permai } \\
\text { Timur Viii Rt/Rw } \\
001 / 005 \mathrm{Kec} . \\
\text { Rungkut } \\
\text { Surabaya }\end{array}$ & $\begin{array}{l}\text { Swasta/ } \\
\text { perorangan }\end{array}$ & S1 psikologi & psikolog praktek \\
\hline 3 & $\begin{array}{l}\text { Sirikit Syah, } 39 \\
\text { Th, Rungkut Asri } \\
\text { Timur VII/ } 8 \\
\text { Surabaya }\end{array}$ & Surabaya post & S1 bhs Inggris & $\begin{array}{l}\text { wartawan } \\
\text { Surabaya post }\end{array}$ \\
\hline 3 & $\begin{array}{l}\text { Emy Susanti 41, } \\
\text { Th, Jl } \\
\text { Dharmawangsa } \\
\text { Dalam 2-4 } \\
\text { Surabaya }\end{array}$ & Fisip UNAIR & S2 Sosiologi & $\begin{array}{l}\text { Dosen Fisip } \\
\text { kepala pusat } \\
\text { studi wanita }\end{array}$ \\
\hline 4 & $\begin{array}{l}\text { Luthfi Rachman, } \\
67 \text { th, Pandean } \\
\text { I/32 Kel. Peneleh } \\
\text { Surabaya }\end{array}$ & Swasta & $\begin{array}{l}\text { Akademi Wartawan } \\
\text { surabay }\end{array}$ & $\begin{array}{l}\text { Budayawan } \\
\text { muslim/ } \\
\text { pengamat socia } \\
\text { kemasyarakatan }\end{array}$ \\
\hline 5 & $\begin{array}{l}\text { Supratono, } 43 \text { th, } \\
\text { Jl Gubeng Jaya } 2 \\
\text { K } 64 \text { Surabaya }\end{array}$ & $\begin{array}{l}\text { Kanwil Deppen } \\
\text { Porp. Jatim }\end{array}$ & S2 Sospol & $\begin{array}{l}\text { PNS Kanwil } \\
\text { Deppen Prop. } \\
\text { Jatim }\end{array}$ \\
\hline
\end{tabular}

Sumber : Hasil penelitian penulis pada tahun 2000 pada kasus tindak pidana pornografi (kejahatan kesusilaan) 
Bahwa dengan disiplin keilmuan yang berbeda tersebut tentunya pandangan dan pendapat mereka berbeda pula. Yang patut dicermati adalah keterangan mereka belum ada yang bendasarkan kepada ayat-ayat dalam AlQuran, Injil maupun Weda Sarasmuscaya.

Dengan demikian keterangan ahli/ saksi ahli pornografi yang diperoleh penyidik dalam kasus tindak pidana pornografi selama ini dapat fikatakan secara komprehensif kurang memiliki nilai pembuktian yang sah sebagaimana dimaksud dalam pasal 284 ayat (1) KUHP. Pandangan yang berbeda khususnya terhadap tulisan-tulisan, cerita yang berkaitan dengan nuansa sexual dan gambar-gambar yang bersifat pornografi, dampaknya nampak pada putusan Pengadilan yang relatif ringan dan tidak membuat jera kepada para pelaku tindak pidana pornografi.

Dampak yang lain disatu pihak adalah penerbitan oleh beberapa kalangan mass media dengan tujuan menaikkan oplahnya melalui cara memuat tulisan, cerita yang bernuansa sexual dan gambar-gambar porno tersebut makin marak di pasaran, dilain pihak para pengusaha mass media cetak tidak mempedulikan dampak buruk yang timbul atas peredaran majalah/ tabloid, buku buku porno berisi tulisan cerita sexual ditengah-tengah masyarakat, khususnya bagi kalangan yang belum dewasa, seperti contoh kasus-kasus perkosaan terhadap balita, kasus percabulan antara anak dengan anak yakni akibat dari ekses mass media, tabloid yang memuat tulisan sexual dan gambar porno termasuk VCD porno.

\section{SUMPAH ATAU JANJI TERHADAP SAKSI ATAU SAKSI AHLI DALAM PENYIDIKAN}

Dalam penyidikan bahwa sumpah atau janji terhadap saksi atau saksi ahli dalam hal tertentu mutlak diperlukan agar Berita Acara Pemeriksaan saksi atau saksi ahli tersebut mempunyai kekuatan hukum yang nilainya sebagai alat bukti yang sah sebagainama dimaksud dalam pasal 184 ayat (1) KUHAP yaitu berupa alat bukti keterangan saksi atau keterangan ahli, demikian pula dalam pemeriksaan di Sidang Pengadilan bahwa keterangan saksi atau saksi ahli mempunyai kekuatan hukum sebagai alat bukti yang sah bilamana sebelum memberikan keterangan lebih dahulu terhadap saksi atau saksi ahli yang bersangkutan telah 
dilakukan pengambilan sumpah atau janji pada waktu di Sidang pengadilan.

Pengambilan sumpah atau janji dapat dilakukan pula pada saat ditingkat pemeriksaan oleh penyidik, apabila diperkirakan bahwa nantinya saksi atau saksi ahli tersebut tidak akan dapat hadir pada saat pemeriksaan didepan Sidang Pengadilan dan Hakim cukup dapat membacakan berita acara saksi atau saksi ahli tersebut yang telah dilengkapi berita acara penyumpahan atau janji tersebut.

Bahwa maksud untuk dilakukan penyumpahan atau janji ini tidak lain adalah agar keterangan atau pendapatnya (jika ahli tersebut yang memberikan keterangan) yang telah dituangkan dalam Berita Acara Pemeriksaan Saksi atau saksi ahli dapat berfungsi sebagai alat bukti surat dan dapat pula kesaksiannya berfungsi disamping membuat terang perkaranya juga sebagai alat bukti yang sah (vide pasal 184 ayat (1) KUHAP).

Keterangan saksi atau ahli (termasuk ahli Pornografi) yang tidak disumpah atau mengucapkan janji, tidak dapat dianggap sebagai alat bukti sah, tetapi hanyalah merupakan keterangan yang dapat menguatkan keyakinan keyakinan Hakim pada waktu menjatuh- kan putusan di sidang pengadilan.

Perlunya untuk pengambilan sumpah atau janji terhadap saksi atau saksi ahli ditingkat penyidikan adalah adanya dugaan atau atas keterangannya saksi atau saksi ahli bahwa yang bersangkutan dimungkinkan tidak akan dapat hadir dalam pemeriksaan di Sidang Pengadilan dengan alasan sakit atau berhalangan karena sebab-sebab yang lainnya.

Mendasarkan Pasal 79 ayat (2) KUHAP dan uraian sebagaimana seperti tersebut diatas berlaku baik untuk saksi maupun saksi ahli (ahli Pornografi) dengan ketentuan rnengucapkan sumpah atau janji serta akan memberikan keterangan yang sebaik-baiknya dan yang sebenar benarnya seperti yang dilihat, didengar dan dialami serta khusus bagi yang bertindak ahli/saksi ahli yakni sesuai dengan pengetahuan dalam bidang keahliannya.

Proses penyidikan kasus tindak pidana kesusilaan/kesopanan (pornografi) tidak bisa dilepaskan dari upaya paksa berupa pemanggilan, bahkan penangkapan, penggeledahan, penyitaan dan tindakan penyidikan lainnya, oleh karenanya hendaknya penyidik sesuai kewenangannya dapat menunjuk / 
menentukan keterangan ahli/saksi ahli pornografi terlebih dahulu dari Departemen Agama RI/Kanwil Depag Propinsi dengan pertimbangan bahwa penelitian dan pendapatnya memiliki visi atau pandangannya tentang pornografi mendasarkan hukum agama (Islam, Kristen, Katholik dan Hindu) dan bila dirasakan masih perlu penyidik dapat meminta pakar yang bidang pekerjaannya masih ada relevansinya dengan masalah-masalah kewanitaan (misal Pusat Penelitian Wanita Perguruan Tinggi, vide pasal 7 ayat (1) huruf $h$, pasal 120 (1), pasal 179 ayat (1) KUHAP), hal ini dengan maksud agar memenuhi bukti permulaan cukup dan tidak terjadi penyalahgunaan wewenang diskresi penyidik.

\section{PENUTUP}

Dalam melaksanakan wewenang diskresi penyidik dalam memilih dan menentukan ahli atau saksi ahli dirasakan masih kurang tepat karena pandangan mereka tentang pornografi belum memiliki dasar hukum yang jelas dimana visi atau pandangan mereka tergantung dari latar belakang pekerjaan dan disiplin keilmuannya, dampaknya adalah terhadap putusan pengadilan ringan (hukuman percobaan).

Bahwa dalam penanganan/ penyidikan kasus tindak pidana kesusilaan/kesopanan (pornografi) selayaknya dalam mengoptimalkan pembuktian diperlukan yang bertindak ahli/saksi ahli dan unsur agama (Islam, Katholik dan Hindu) karena visi atau pandangannya terhadap pornografi tersebut adalah dari ayat-ayat hukum agama disamping itu tingkat pendidikan yang bersangkutan (ahli/ saksi ahli) minimal Strata (satu) dibidangnya.

Dalam hal dirasakan masih diperlukan keterangan ahli/saksi ahli (pornografi), penyidik dapat menunjuk ahli/saksi ahli dan psikologi dan pendidikan hal ini dengan pertimbangan bahwa permasalahan pornografi masih dekat kaitannya/relevansinya dengan moral, etika dan agama.

Prosedur penyidikan dalam mendapatkan keterangan ahli/saksi ahli dimaksud agar mendasarkan kepada peraturan perundang-undangan yang berlaku (pensitaan) dan dilaksanakan sesuai dengan juklak/juknis Kapolri No. Pol. Juklak/04/II/1982 tanggal 18 Pebruari 1982 tentang proses 
penyidikan tindak pidana.

Dengan prosedur yang benar dalam mendapatkan keterangan ahli/saksi ahli pornografi seperti sebagaimana terurai diatas maka tindakan penyidikan terhadap kasus tindak pidana kesusilaan/ kesopanan (pornografi) dapat dikatakan bukti permulaan cukup (vide pasal 17 KUHAP) sehingga bila melaksanakan upaya paksa (panggil, tangkap, tahan, geledah dan sita), serta tindakan penyidikan lainnya tidak ada tuntutan dari pihak lain yang merasa dirugikan baik tuntutan praperadilan maupun tuntutan hukum dalam bentuk yang lain (ganti rugi vide pasal 1365 KUHP perdata).

\section{DAFTAR PUSTAKA}

Ade, Sutrisno, 1987, Taktik dan Teknik menggali motif pidana dalam menyusun berita acara penyidikan kepolisan, Surabaya.

Algra, N.E., 1983, Mula Hukum, Binacipta, Bandung.

Allott, Antony, 1980, The Limits of Law, Butterwort (Publishers) Inc., London.

Atmosudirdjo, Prajudi, 1981, Hukum Administrasi Negara, Cetakan IV, Ghalia Indonesia, Jakarta.
Bodjeber Zein, 1981, Kitab UndangUndang Hukum Acara Pidana dan Uraian, Hirokurezafari, Jakarta.

Brotodiredjo, Soebroto, 1983, Asas-Asas Wewenang Kepolisian, Majalah Byayangkara Nomor 06, PTIK, Jakarta.

Chambliss, William, J., 1969, Crime and legal Process, Mcgraw Hill Book Company, New York.

Dahlan Raoib, Jasim Hamidi, Nimatull HUda, 1999, Teori Hukum dan Konstitusi, PT. Raja Grafindo Persada, Jakarta.

Djoko, Prakoso, 1997, Polisi sebagai Penyidik Dalam Penegakan Hukum, Penerbit Bina Aksara, Jakarta.

Harahap Yahya, 1993, Pembahasan Permasalahan dan Penerapan KUHAP, Pustaka Kartini, Jakarta.

Hart, H.L.A., 1961, The Concept of law ELBS, oxford University Press.

John, Sohnon Sir, 1937, Jurisprudence Ninth Edition, London Sweet Maxwell.

Jurik, Nancy, C., Ehrlich Martin Susan, 1996, Doing Justice Doing Gender, (International Education and Prefesional Publisher), Thousand doks London.

Karyadi, M., 1976, Pembahasan Tugas dan Wewenang (Diskresi Kepolisian), Politea, Bogor. 
Klelana, Momo, 1994, Hukum kepolisian, Penerbit PT. Grasindo, Jakarta.

Nurul Afiah Ratna, 1986, Praperadilan dan Ruang Lingkupnya, CV. Akademika Pressindo, Jakarta.

Orchard, Gerald, 1998, Principles of Criminal Law, New Zealand.

Rahardjo Sutjipto, 1978, Pemanfaatan IImu-ilmu Sosial bagi Pengembangan IImu Hukum, Alumni, Bandung.

Rainton, D., 1974, Police Descration, A Studi of How it Works in Sussex Police, Review Juli.

Rasyidi, Lili, 1971, Dasar-dasar Filsafat Hukum, Citra Aditya Bakti, Bandung.

Rawls, John, 1971, A Theory of Justice, Harvard University Press Camj Bridge, Massachussetts.

Rosita Lily, 1996, Hukum Pembuktian Dalam Perkara Pidana, Sinar Jaya, Surabaya.

Samudra Teguh, 1992, Hukum Pembuktian Dalam Acara Perdata, Alumni, Bandung.
Seno, Adji Oemar, 1980, Peradilan Bebas Negera Hukum, Erlangga, Jakarta.

Sidharta, Arif, 1996, Refleksi Tentang Hukum, Citra Aditia Bakti, Bandung.

Soemadjipradja, Rd., Achmad S., 1975, Pokok-Pokok Hukum Acara Pidana, Alumni Bandung.

Soekanto, Soerjono, 1982, Kesadaran Hukum dan Kepatuhan Hukum, Rajawali Press, Jakarta.

Sudarto, 1980, Uraian Pokok-pokok Permasalahan dalam Seminar Kriminologi-IV, Semarang.

Susilo, R. Karyadi, 1989, Kriminalistik IImu Penyidikan Kejahatan, Politica, Bogor.

Sisilo, R., 1992, Prosedur Penyelesaian Perkara Pidana, Politica, Bandung. 